\title{
NIF Project Management System Description
}

August 1997

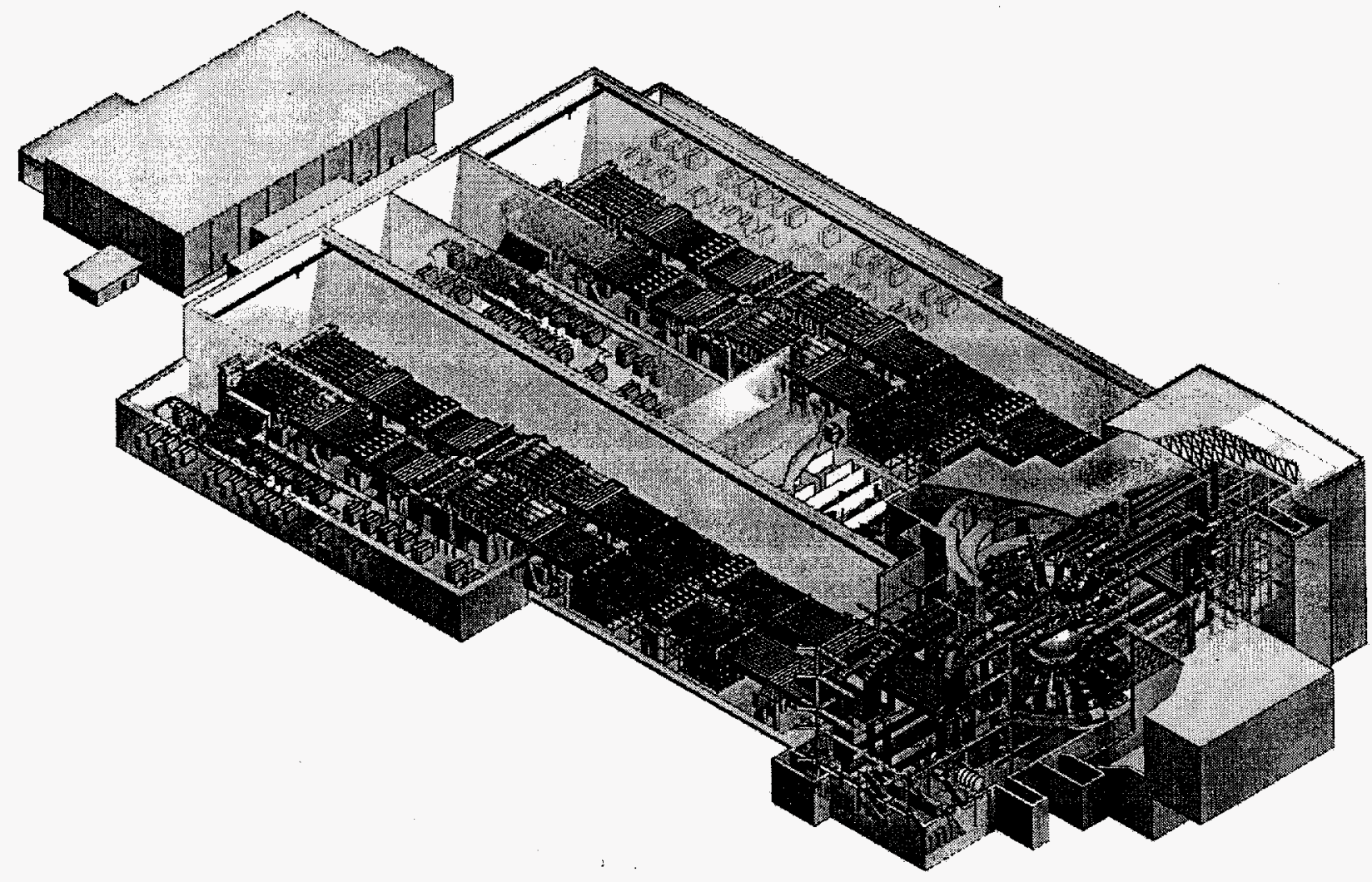




\section{DISCLATMER}

This document was prepared as an account of work sponsored by an agency of the United States Government. Neither the United States Government nor the University of California nor any of their employees, makes any warranty, express or implied, or assumes any legal liability or responsibility for the accuracy, completeness, or usefulness of any information, apparatus, product, or process disclosed, or represents that its use would not infringe privately owned rights. Reference herein to any specific commercial product, process, or service by trade name, trademark, manufacturer, or otherwise, does not necessarily constitute or imply its endorsement, recommendation, or favoring by the United States Govemment or the University of California. The views and opinions of authors expressed herein do not necessarily state or reflect those of the United States Government or the University of California, and shall not be used for advertising or product endorsement purposes.

This report has been reproduced directly from the best available copy.

Available to DOE and DOE contractors from the Office of Scientific and Technical Information P.O. Box 62, Oak Ridge, TN 37831

Prices available from (615) 576-8401, FTS 626-8401

Available to the public from the National Technical Information Service

U.S. Department of Commerce 5285 Port Royal Rd. Springfield, VA 22161 


\section{NIF Project Management System Description}

August 1997 


\section{NIF Project Management} System Description

\section{August 1997}

Prepared by:

C. Robert Wolfe

NIF Quality Assurance Manager

Date

Jon Yatabe

NIF Project Assurance Manager

Concurred:

David C. Rardin

NIF Project Control

Allen J. Levy

NIF Deputy Project Manager

Date

Date

Date

Date

Approved by:

Jeffrey A. Paisner

Date

NIF Project Manager 


\section{Contents}

Introduction .................................................................................................................

1.0 Roles, Responsibilities, and Interface Definition ...................................................... 5

1.1 Project Management System Description ......................................................... 5

1.2 Project Charter ............................................................................................... 5

1.3 Memorandum of Agreement, Interface Description.................................... 5

1.4 Project commitment tracking ……......................................................................... 5

1.5 Technology development.................................................................................... 6

2.0 Baseline definition and change control ......................................................................... 6

2.1 Baseline definition and approval ........................................................................ 6

2.2 Change control.................................................................................................... 6

2.3 Configuration management................................................................................. 7

2.3.1 The Project Data Management System .............................................. $\quad 7$

2.4 Design review and approval ................................................................................ 7

2.5 Completion criteria .................................................................................... 7

3.0 Funds allocation, control and reporting …………................................................... 7

3.1 Budgetary process ............................................................................................. 7

3.2 Funds allocation ................................................................................................ 7

3.3 Cost Account Plans .............................................................................. 8

3.4 Scheduling ...................................................................................................... 8

3.5 Contingency control................................................................................................ 8

3.6 Reporting ............................................................................................... 8

4.0 Procurement........................................................................................................ 9

4.1 Requirements ............................................................................................... 9

4.2 Procurement planning.......................................................................... 9

4.3 Supplier qualification ……............................................................................. 9

4.4 Acceptance …................................................................................................ 9

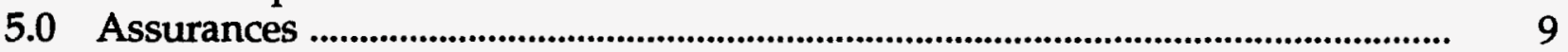

5.1 ES\&H planning ................................................................................................... 9

5.2 Security planning ................................................................................. 10

5.3 Quality Assurance plan ........................................................................................ 10

5.3.1 Process control........................................................................................ 10

5.3.2 Sub-tier Quality Assurance plans ............................................................ 10

5.3.3 Training ...................................................................................................... 11

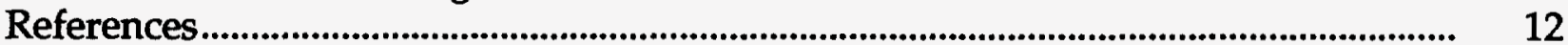

\section{List of Figures and Tables}

Figure 1. Organization of the NIF Project Management System .................................. 3

Table 1. Correspondence between Order 430.1 requirements and elements of the NIF Project Management System ........................................................... 2

Table 2. NIF Project Management System elements ........................................................ 4 


\section{Introduction}

This document has been prepared for two purposes:

1. To demonstrate compliance with the project management requirements of DOE Order 430.1, Life-Cycle Asset Management (LCAM).

2. To summarize in one place the approved Project documents which, taken as a whole, describe the NIF Project Management System.

DOE Order 430.1 identifies 14 requirements of a project management system for line-item projects. ${ }^{1}$ Table 1 lists these requirements and also relates them to elements of the NIF Project Management System. Figure 1 shows the organization of the System into five logical groupings, with arbitrary sequence numbers for ease of reference. Table 2 lists the System elements in order of these sequence numbers. Each section in the remainder of this document is numbered in parallel with the sequence number of the element it describes.

While complying with the requirements of the Order, the NIF Project Management System contains some elements that do not correspond directly to those requirements (marked "other" in Figure 1). These elements have been developed by the Project either in response to other requirements or to extend management control beyond that called for in Order 403.1. 
Table 1. Correspondence between Order 430.1 requirements and elements of the NIF Project Management System.

\begin{tabular}{|c|c|c|}
\hline Order 430.1 requirement ${ }^{1}$ & $\begin{array}{l}\text { NIF Project Management } \\
\text { System element }\end{array}$ & $\begin{array}{l}\text { Defining } \\
\text { reference(s) }\end{array}$ \\
\hline \multicolumn{3}{|c|}{ Prior to the commencement of conceptual design [paragraph (a)]: } \\
\hline $\begin{array}{l}1 \text { - Mission need } \\
2 \text { - Functional requirements } \\
3 \text { - Eost and schedule } \\
4 \text { - Environmental strategy } \\
5 \text { - Project technical and organizational } \\
\text { interfaces } \\
6 \text { - Integration with other project activities }\end{array}$ & $\begin{array}{l}\text { 1.2 - Project charter } \\
\text { 1.2 - Project charter } \\
\text { 3.3 - Cost account process } \\
\text { 3.4 - Scheduling } \\
\text { 5.1 - ES\&H planning } \\
\text { 1.3 - MOA, interface definition } \\
\text { 1.5 - Technology development } \\
\text { 1.4 - Commitment control and tracking } \\
\text { 3.4 - Scheduling }\end{array}$ & $\begin{array}{c}2-7 \\
8-10 \\
30-32 \\
33-35 \\
46-54 \\
11,12 \\
14,15 \\
13 \\
33-35 \\
\end{array}$ \\
\hline \multicolumn{3}{|c|}{ Prior to the commencement of execution [paragraph (b)]: } \\
\hline 1 - Project objectives & $\begin{array}{l}\text { 2.4 - Design review and approval } \\
\text { 3.4 - Scheduling } \\
\text { 4.2 - Procurement planning }\end{array}$ & $\begin{array}{l}24-26 \\
33-35 \\
38-40 \\
\end{array}$ \\
\hline 2 - Scope, schedule and cost baselines & $\begin{array}{l}2.1 \text { - Baseline definition and approval } \\
\text { 3.1 - Budgetary process } \\
\text { 3.2 - Funds allocation }\end{array}$ & $\begin{array}{c}16-21 \\
28,29 \\
17 \\
\end{array}$ \\
\hline 3 - Life-cycle cost analysis & $\begin{array}{l}3.1 \text { - Budgetary process } \\
3.3 \text { - Cost account process }\end{array}$ & $\begin{array}{l}28,29 \\
30-32 \\
\end{array}$ \\
\hline 4 - Preliminary safety assessment & 5.1 - ES\&H planning & $46-54$ \\
\hline $\begin{array}{l}5 \text { - Project controls, including baseline } \\
\text { change control, change control } \\
\text { thresholds, and statusing }\end{array}$ & $\begin{array}{l}2.1 \text { - Baseline definition and approval } \\
\text { 2.2 - Change control } \\
\text { 2.4 - Design review and approval } \\
\text { 3.3 - Cost account process } \\
\text { 3.6 - Reporting } \\
\text { 3.5 - Contingency control } \\
\end{array}$ & $\begin{array}{c}16-21 \\
17,22 \\
24-26 \\
30-32 \\
16 \\
17,22,36 \\
\end{array}$ \\
\hline 6 - Completion of NEPA documentation & 5.1 - ES\&H planning & $46-54$ \\
\hline 7 - Verification of performance criteria & $\begin{array}{l}\text { 1.5 - Technology development } \\
\text { 2.5 - Completion criteria } \\
5.3 \text { - Quality Assurance Plan }\end{array}$ & $\begin{array}{c}14,15 \\
27 \\
24,25,56-58 \\
\end{array}$ \\
\hline 8 - Design alternatives & 1.5 - Technology development & 14,15 \\
\hline
\end{tabular}






\footnotetext{
(a) = Element required prior to the commencement of conceptual design

[Order 430.1, Paragraph $60(7)(a)]$
(b) $=$ Element required prior to the commencement of execution [Order 430.1, Paragraph 6e(7)(b)]
}

(other) $=$ Element either developed by the Project to extend controls beyond the minimum requirements of $\mathbf{4 3 0 . 1}$ or developed to comply with other requirements. 
Table 2. NIF Project Management System elements. Each system element is described in the paragraphs following this table.

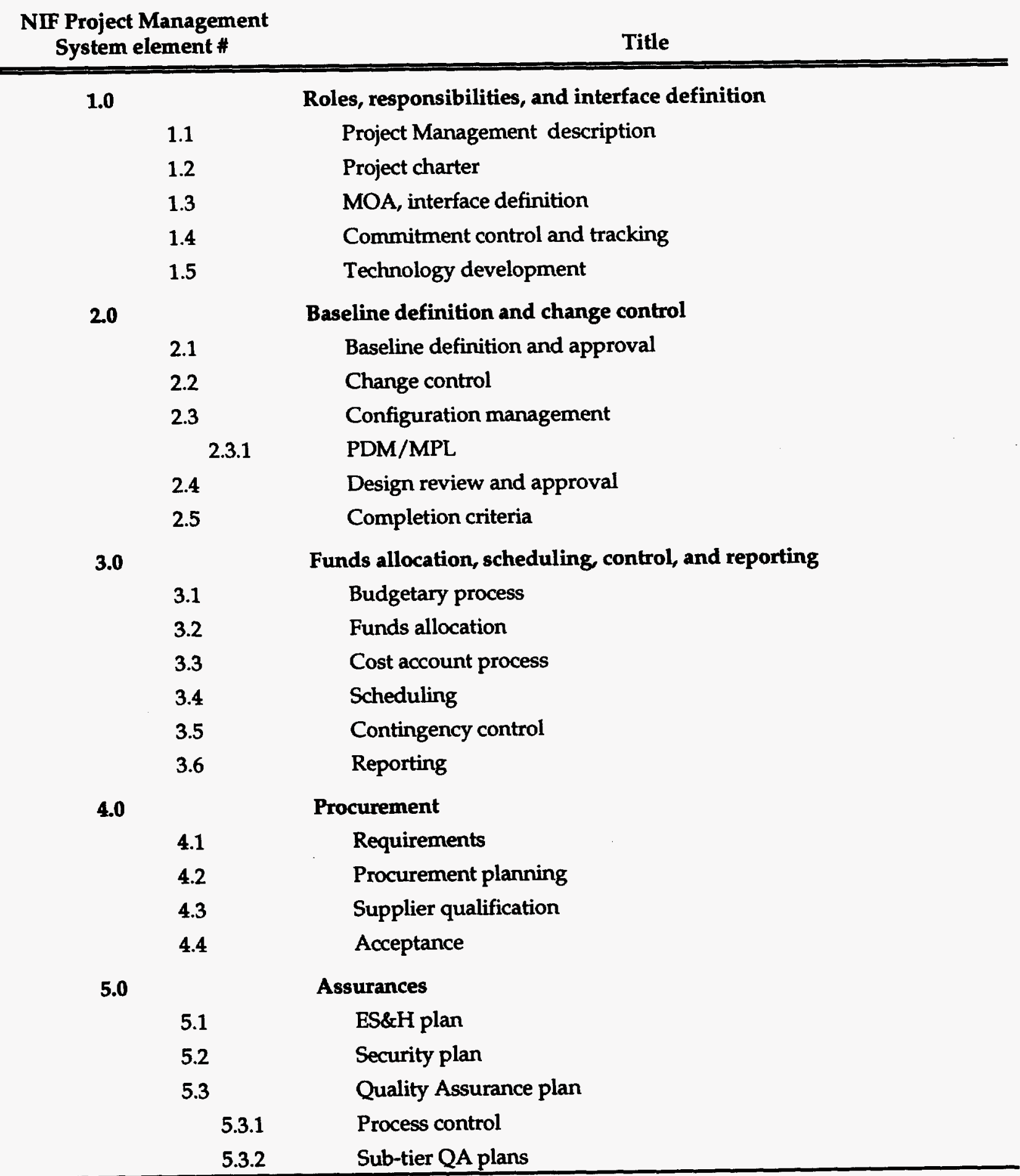




\subsection{Roles, Responsibilities, and Interface Definition}

\subsection{Project Management System Description}

The NIF Project Management System is described in summary form by this document. This document briefly touches on each element and provides references to other Project documents that describe the activity in detail.

\subsection{Project Charter}

The Project Charter was established by the Justification of Mission Need, ${ }^{2}$ which accompanied CD 1 (formerly KD 0), Approve Mission Need, and was reinforced by approval of CD 2 (formerly KD 1), Approve New Start. ${ }^{3}$ A definition of work scope has been developed for each phase of the Project. The NIF Project Charter for the NIF Conceptual Design ${ }^{4}$ described scope of the conceptual design activities. This was supplemented by the Conceptual Design Scope and Plan. 5 Subsequent phases of the Project were described in the Title I Design Plan ${ }^{6}$ and the Title II Design Plan.7

Regulatory requirements and means for their implementation are delineated in the Functional Requirements/Primary Criteria. 8 The process used to develop and revise these requirements is described in NIF Procedure 6.5.9 This process adheres to the necessary and sufficient criteria of DOE M 450.3-1.10

\subsection{Memorandum of Agreement, Interface Description}

The roles of institutional participants in the Project were described in early management documents. The Memorandum of Agreement Between Participating Laboratories ${ }^{11}$ established the primary design responsibilities for the four DOE Laboratories involved in the NIF. These participants are LANL, LLNL, SNL, and UR/LLE. The relationships between ONIF and OICF at DOE/HQ were subsequently established. 12

\subsection{Project Commitment Tracking}

These activities are described by NIF Procedure 1.8, Project Action Tracking. ${ }^{13}$ Each senior manager is responsible for managing commitments in his or her area of responsibility according to this guidance. 


\subsection{Technology Development}

Activities conducted within technology development provide for verification of performance criteria and the test and evaluation of design alternatives (e.g., Beamlet Test Program). The integration and control of NIF supporting technology are managed in the NIF Special Equipment organization. 14 Strategy and rationale for technology development are described in the Core Science \& Technology Plan. 15

\subsection{Baseline Definition and Change Control}

\subsection{Baseline Definition and Approval}

There are three baselines (cost, schedule, and technical) managed by the Project. Baseline definition and approval are outlined in the NIF Project Execution Plan ${ }^{16}$ and are described in further detail in NIF Procedure 1.7, Project Change Control. 17 Procedure 1.7 describes the change control thresholds for each baseline. These thresholds define the jurisdiction of the Baseline Change Control Boards (BCCBs).

The technical baseline is derived from the top-level criteria that flow down from the Justification of Mission Need. ${ }^{2}$ The Project Manager relies upon advice of the ICF Program scientific staff for technical baseline definition, according to NIF Procedure 9.1.18 A series of documents extends the technical baseline to design criteria in increasing detail. These documents are:

- System Design Requirements ${ }^{19}$ (SDRs).

- Subsystem Design Requirements 20 (SSDRs).

- Interface Control Documents ${ }^{21}$ (ICDs).

These documents are prepared for each engineering and support system of the NIF Project (WBS 1.2 to 1.10 ).

\subsection{Change Control}

Change control within the established baselines is described in NIF Procedure 6.4, Engineering Change Requests. 22 The Configuration Control Board (CCB) is established by this procedure. This Board reviews and approves Engineering Change Requests (ECRs) within its jurisdiction. If the impact of a change exceeds a Project baseline (cost, schedule, or technical), a baseline change proposal (BCP) is prepared according to Procedure 1.7.17 


\subsection{Configuration Management}

The NIF Configuration Management Plan $^{23}$ describes configuration management of technical design documents. The Plan is implemented by NIF Procedure 6.4.22

\subsubsection{The Project Data Management System}

The Project Data Management System (PDM) is a software product described in Procedure 6.4. ${ }^{22}$ The protocol of this software is used as a tool by System Engineers and Project Management to manage the revision process for technical design documentation (criteria, drawings, calculations, and specifications).

\subsection{Design Review and Approval}

Design review and approval are governed by NIF Project Procedure 5.1.24 During Title I, design review and approval dealt primarily with criteria development. Title II emphasizes design compliance with those established criteria. Management assessment ${ }^{25}$ and audit ${ }^{26}$ processes are selectively used to verify compliance.

\subsection{Completion Criteria}

Completion of the Project has been defined in accordance with direction from the Level 1 BCCB, "in a cost effective manner that integrates the Project with the ICF Program." 27

\subsection{Funds Allocation, Control, and Reporting}

\subsection{Budgetary Process}

The budgetary process is driven by the DOE Congressional budget submission process. The bottom-up cost estimates made during the Conceptual Design, and subsequently updated during Title I Design, are the basis for the NIF Project Data Sheet. ${ }^{28}$ NIF Procedure 1.2, Cost Estimating, ${ }^{29}$ describes the bottom-up cost estimate process.

\subsection{Funds Allocation}

Funds allocation is governed by the DOE and the Laboratory Project Office. The $\mathrm{BCCBs}$ establish the initial allocation and approve changes. The thresholds that define 
the jurisdiction of these Boards are described in Project Procedure 1.7, Project Change Control.17

\subsection{Cost Account Plans}

Cost Account Plans (CAPs), defined according to the Project Work Breakdown Structure ${ }^{30}$ (WBS), are prepared for system engineering and support areas within the Project. Project Procedure 1.9, Generation of Cost Account Plans, 31 describes the process. Milestones within the CAPs are the basis for performance tracking. Direction from the Project Office ${ }^{32}$ provides guidance to CAP managers for status reporting.

\subsection{Scheduling}

The top-level Project schedule is tied to the Critical (formerly Key) Decision process. The schedule of Critical (formerly Key) Decisions for the NIF Project was first documented in the NIF Conceptual Design Report. ${ }^{33}$ These milestones are managed in the Integrated Project schedule. ${ }^{34}$

- CD 1 (formerly KD 0)-Approve mission need 1/15/93.

- CD 2 (formerly KD 1)-Approve new start 10/20/94.

- KD 1' (Dellums process)-NIF studies complete 12/20/95.

- CD 3-Approve construction start 3/7/97.

- CD 4-Project complete 10/1/03.

The Integrated Project Schedule is the basis for all lower-tier schedules and is prepared and maintained according to the process described in Procedure 1.3, Schedule Preparation. 35 Approved and controlled milestones identified in the CAPs provide detail for the current fiscal year.

\subsection{Contingency Control}

Contingency was calculated in a bottom-up fashion during Conceptual Design and updated during Title I Design as part of the cost estimating activities. ${ }^{36}$ Contingency controls are implemented through functioning of the BCCBs. The Level 1, 2, 3 BCCBs ${ }^{17}$ and, to a limited extent, $\mathrm{CCB} 4^{22}$ have the authority to allocate contingency.

\subsection{Reporting}

Reporting is the responsibility of the Laboratory Project Office. The requirements for monthly and quarterly reports are described in Section 4.6.2, Project Execution Plan. 16 


\subsection{Procurement}

\subsection{Requirements}

Procurements for the NIF Project will follow the Laboratory's DOE-approved procurement system. This system consists of the "Laboratory Commercial Procurement Procedures" and, as applicable, the University's Laboratory Standard Practices Manual as supplemented by LLNL's local implementation (Supplemental Instructions). These topics are summarized in NIF Procedure 7.2, Standard Procurement Policies and Practices. ${ }^{37}$

\subsection{Procurement Planning}

Procurement planning follows the CAPs and the Integrated Project schedule. The NIF Acquisition Plan 38 describes the strategy for selection of contract type. The NIF Procurement Plan $^{39}$ lists the scheduled procurements and their estimated dollar value. NIF Procedure 7.4, Special Equipment Procurement Process, 40 describes the process that technical requesters must follow to develop and issue procurement documents.

\subsection{Supplier Qualification}

Qualification of NIF special equipment and optics suppliers is described in NIF Procedure 7.1, Supplier Qualification. ${ }^{41}$ The preselection process for construction subcontractors is described elsewhere. 42 Vendor surveillance is described in NIF Procedure 7.3.43

\subsection{Acceptance}

Acceptance requirements (e.g., inspection and testing) will be defined in specifications written by the technical requesters. The content and organization of specifications are described in NIF Procedure 8.2, Standard Specification Content.44 A program that institutes receiving inspections to ensure that suspect/counterfeit items are not incorporated into Project work is described by NIF Procedure 8.1.45

\subsection{Assurances}

\subsection{ES\&H Planning}

The NIF ES\&H Management Plan 46 describes the overall approach to environment, safety, and health (ES\&H) management by the NIF Project. Individual activities are 
addressed in sub-tier documents, such as the ALARA Program description, ${ }^{47}$ PHA, ${ }^{48}$ PSAR, 49 Construction Safety Program, 50 Environmental Permits, NIF Risk Management Plan, 51 Decommissioning Plan, 52 and Mitigation Action Plan. ${ }^{53}$

ES\&H responsibilities for the NIF Project are implemented by line management beginning with the Project Manager. Responsibilities are specified in the Project Execution Plan ${ }^{16}$ and expanded in NIF Management Descriptions, 54 the ES\&H Management Plan, ${ }^{46}$ and the Construction Safety Program. 50

\subsection{Security Planning}

Security planning is managed by the Laser Programs Assurance Office. The NIF Security Procedure (draft) describes security requirements and design features specific to the NIF.

\subsection{Quality Assurance Plan}

Quality Assurance for the NIF is managed according to the NIF Quality Assurance Program Plan.55 This Plan complies with the requirements of DOE Order 5700.6C. A graded approach is implemented by NIF Procedure 1.6,56 which identifies the logical process by which Q-levels are assigned to Project elements based upon consequences in the event of failure. Management assessments are described in NIF Procedures $9.2^{24}$ and 10.1.25

\subsubsection{Process Control}

Project process control is achieved by documented procedures contained in the NIF Project Control Manual. 57 This manual is kept current by means of controlled distribution. Holders of the Manual are registered, automatically receive updates, and are required to keep the Manual current. Furthermore, the Manual must be relinquished upon leaving the Project. The manual currently contains approximately 30 procedures, some of which are cited in this Project Management System Description.

\subsubsection{Sub-tier Quality Assurance Plans}

Sub-tier Quality Assurance Plans are required of major subcontractors. In addition, organizations within the NIF Project may write their own. Currently, five sub-tier Plans have been written by the following:

- Parsons Infrastructure and Technology Group (LTAB A/E firm).

- A. C. Martin \& Associates (OAB A/E firm).

- NIF Integrated Computer Controls organization (WBS 1.5), Software QA Plan. ${ }^{58}$

- Laser Materials and Optics Technology organization (WBS 1.6), QA Plan for Laser Materials and Optics Technology. 59

- Sverdrup Facilities, Inc. (Conventional Facilities Construction Mangement firm). 


\subsubsection{Training}

The training to ensure competency commensurate with responsibility is documented in the NIF Project Training file. In the file, each Laboratory employee and outside subcontractor has a professional resume and job-specific training record. Maintenance of training records is described in two Project prodedures. ${ }^{60}$ 


\section{References}

1. DOE Order 430.1, Life-Cycle Assets Management; paragraph 6e (7).

2. Justification of Mission Need, (1/93) see NIF Conceptual Design Report Appendix A, Vol. 1, bk. 1, UCRL-PROP-117093.

3. CD 2 letter (formerly KD 1), Approve New Start (10/21/94).

4. Project Charter for NIF Conceptual Design (3/93).

5. Conceptual Design Scope and Plan (NIF-93-043, 9/93), also App.A Vol 1 Bk 3 of reference \#32.

6. NIF Title I Design Plan, NIF-96-650.

7. NIF Title II Design Plan, NIF-0001249 (3/97).

8. NIF Functional Requirements and Primary Criteria, Rev 1.6, NIF-0001006-OC (3/97).

9. NIF Procedure 6.5, Preparation of Primary Criteria/Functional Requirements, NIF0001459.

10. DOE M 450.3-1, The DOE Closure Process for Necessary and Sufficient Sets of Standards $(3 / 1 / 96)$.

11. Memorandum of Agreement between LLNL, LANL, SNL, and LLE with respect to NIF activities, NIF-93-018 (8/10/93).

12. Memorandum of Understanding Regarding Relationship between the Office of the National Ignition Facility and the Office of Research and Inertial Fusion (3/27/95).

13. NIF Procedure 1.8, Project Action Tracking, NIF-95-666.

14. NIF Project memorandum, Restructuring of the NIF Special Equipment Organization, NIF-0001562.

15. Core Science and Technology Development Plan for Indirect-Drive ICF Ignition, UCRL-ID-117076, Rev 1 (12/95).

16. NIF Project Execution Plan, CD-079 (4/96).

17. NIF Project Procedure 1.7, Project Change Control, NIF-95-667.

18. NIF Procedure 9.1, Project Scientist's Advisory Panel, NIF-95-462.

19. NIF Procedure 6.1, Preparation of System Design Requirements, NIF-93-251.

20. NIF Procedure 6.2, Preparation of Subsystem Design Requirements, NIF-93-252.

21. NIF Procedure 6.3, Preparation of Interface Control Documents, NIF-95-662.

22. NIF Project Procedure 6.4, Engineering Change Requests, NIF-0000280.

23. NIF Configuration Management Plan, NIF-96-070).

24. NIF Procedure 5.1, Title II Design Review, NIF-0002174.

25. NIF Procedure 9.2, Management Assessments, NIF-000967.

26. NIF Procedure 10.1, Independent Assessments, NIF-000281.

27. NIF Project memorandum; J. Paisner, NIF Project Completion Criteria, NIF-0001587 $(2 / 27 / 97)$.

28. See Appendix F of the PEP, Ref. \#16.

29. NIF Procedure 1.2, Cost Estimating, NIF-0001205.

30. NIF Work Breakdown Structure Rev. 17, NIF-5000220 (4/22/97).

31. NIF Procedure 1.9, Generation of Cost Account Plans (CAPs), in process. 
32. NIF Project memorandum, J. A. Paisner, Monthly CAP Status and Reporting Reporting - Overall Progress, Accomplishments, and Cost Account Plan (CAP) Status, NIF-0002236.

33. NIF Conceptual Design Report, UCRL-PROP-117093, Chapter 8 Integrated Project Schedule, specifically Table 8-1 Major NIF Project schedule milestones and Figure 8-1 NIF Summary Schedul.e.

34. NIF Project memorandum, S. Kumpan, NIF Quarterly Report (3/97) Attachment 1, NIF-0002038.

35. NIF Project Procedure 1.3, Schedule Preparation, NIF-000320.

36. NIF Project memorandum, W. Williams, Title I Contingency Estimate, NIF-000538 $(8 / 27 / 96)$.

37. NIF Procedure 7.2, Standard Procurement Policies and Practices, NIF-0001169.

38. NIF Acquisition Plan, NIF-96-251.

39. NIF Procurement Plan, NIF-0001028.

40. NIF Procedure 7.4, Special Equipment Procurement Process, in preparation.

41. NIF Procedure 7.1, Supplier Qualification, NIF-0001014.

42. NIF Project memorandum, V. Davis, NIF Construction Subcontractor Process (8/96).

43. NIF Procedure 7.3, Vendor Surveillance, NIF-96-398.

44. NIF Procedure 8.2, Standard Specification Content, NIF-0002052.

45. NIF Procedure 8.1, Suspect/Counterfeit Items Detection and Prevention, NIF0001458.

46. NIF ES\&H Management Plan, NIF-95-599.

47. described in ref. \#46, Section 2.1 .

48. Preliminary Hazards Analysis for the National Ignition Facility (PHA) 12/93, UCRL-ID-116983 (also contained in ref. \#32, Appendix A vol 2 bk 4).

49. NIF Preliminary Safety Analysis Report (PSAR), UCRL-ID-123759 (9/30/96).

50. Construction Safety Program for the NIF, UCRL-ID-125990 (1/14/97).

51. NIF Risk Management Plan, NIF-0001564.

52. NIF Decommissioning Plan, NIF-0001670.

53. Mitigation Action Plan for NIF, NIF-0001726.

54. NIF Management Descriptions, NIF-0002996.

55. NIF Quality Assurance Program Plan, NIF-000618.

56. NIF Procedure 1.6, Assignment of Quality Assurance Levels, NIF-000320.

57. NIF Project Control Manual Rev 5, NIF-0001554 (2/13/97).

58. Software QA Plan for the NIF Integrated Computer Control System, NIF-000288.

59. NIF QA Plan for Laser Materials and Optical Technology, NIF-96-276.

60. NIF Procedure 2.1, Personnel Qualification Approval and Records Retention, NIF-94-016, and NIF Procedure 2.2, Personnel Orientation and Training, NIF-96-012. 
